\title{
Visceral Larva Migrans Presenting with Hypereosinophilia
}

\section{Hipereosinofili ile Başvuran Bir Pediatrik Olgu: Viseral Larva Migrans}

\section{Çiğdem Ecevit, Özlem Bağ, Canan Vergin, Aysel Öztürk}

Clinic of Pediatric, Behçet Uz Children's Diseases and Surgery Training and Research Hospital, İzmir, Turkey

\begin{abstract}
Toxocariasis is an infection caused by the ingestion of larvae of the dog Toxocara canis or the cat Toxocara cati. A 2.5 year old boy was admitted to our clinics with fever, abdominal pain and loss of appetite. His medical history included geophagia (pica) and amebiasis infection. On admission, the physical examination revealed hepatomegaly and pallor. There was marked eosinophilia with leukocytosis, anemia, hypergammaglobulinemia and elevated serum Ig E titers. Toxocariasis was confirmed by anti-Toxocara IgG and Western blot. After 7 days of albendazole therapy, leukocytosis persisted and a second course of albendazole combined with prednisolone was administered. After 3 weeks, the eosinophil count had decreased and the patient showed resolution of hepatomegaly, but Toxocara serology remained elevated. (Turkiye Parazitol Derg 2013; 37: 58-60)
\end{abstract}

Key Words: Toxocariasis, hypereosinophilia, treatment

Received: 19.12.2011 Accepted: 21.12.2012

\section{ÖZET}

Toksokariazis, kedi ya da köpeklerden Toksokara larvalarının alınması ile ortaya çıkan bir enfeksiyondur. İki buçuk yaşında bir erkek olgu, ateş, karın ağıısı ve iştahsızlık ile başvurdu. Özgeçmişinde pika öyküsü olan ve bir kez de amebiazis geçirme öyküsü olan olgunun, başvuru sırasında hepatomegalisi ve solukluğu saptandı. Lökositoz ve anemiye ek olarak belirgin eosinifilisi, hiperimmunglobulinemisi ve artmış serum IgE düzeyleri tespit edildi. Serolojik olarak anti Toxocara lgG ve Western blot yöntemi ile Toksokariazis tanısı kondu. Yedi günlük Albendazol tedavisini takiben lökositozu süren olguda, ikinci kür Albendazol tedavisi steroid ile birlikte verildi. Üç haftanın sonunda, eosinofil sayısı, hepatomegalisi gerileyen olgunun, serolojik yüksekliği devam etmektedir. (Turkiye Parazitol Derg 2013; 37: 58-60)

Anahtar Sözcükler: Toksokariazis, hipereosinofili, tedavi

Geliş Tarihi: 19.12.2011

Kabul Tarihi: 21.12.2012

\section{INTRODUCTION}

Human Toxocariasis is a syndrome caused by Toxocara canis and Toxocara cati. Young children contract Toxocara infections by ingesting embryonated eggs due to unsanitary play habits. There are three clinical syndromes associated with human toxocariasis: visceral larva migrans (VLM), ocular larva migrans (OLM), and covert toxocariasis (1). The classical presentation of VLM includes fever, hepatomegaly, abdominal pain, and headaches. The major laboratory find- ing is leucocytosis with marked eosinophilia and elevation of IgE levels (2).

\section{CASE REPORT}

A 2.5 year old boy was admitted to our clinics with fever, abdominal distention and abdominal pain. He was anorexic and had a history of pica. He was hospitalized because of amebiasis infection when he was two years old. On admission, he was febrile $\left(38.5^{\circ} \mathrm{C}\right.$,axillar temperature) and he had hepatomegaly (liver edge $4-5 \mathrm{~cm}$ below the right costal

Address for Correspondence / Yazışma Adresi: Dr. Özlem Bağ, Clinic of Pediatric, Behçet Uz Children's Diseases and Surgery Training and Research Hospital, İzmir, Turkey Phone: +90 2324895656 E-mail: bagozlem78@yahoo.com

doi:10.5152/tpd.2013.15 


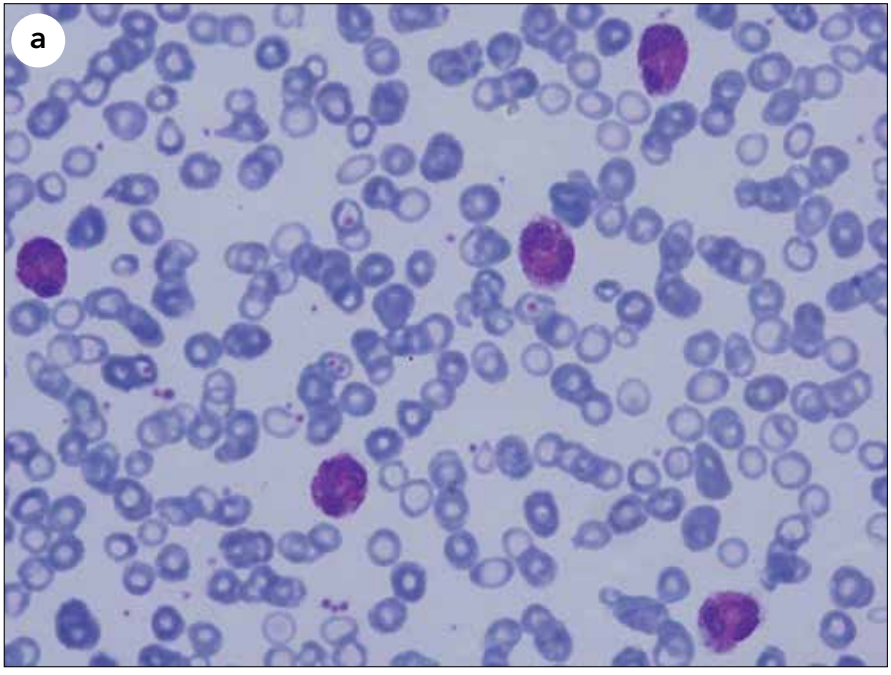

Figure 1a, b. Morphological features in bone marrow

margin). Mild anemia ( $\mathrm{Hb}: 9.4 \mathrm{~g} / \mathrm{dL}$ ) and marked leukocytosis (WBC:36200/ $\mathrm{mm}^{3}$ ) with $83 \%$ eosinophils (absolute eosinophil count $32300 / \mu \mathrm{L}$ ) were present in laboratory findings. The peripheral blood smear showed marked eosinophilia without blasts. Liver function tests, serum glucose, and electrolytes were normal. Serum iron and ferritin were decreased $(10 \mu \mathrm{gr} / \mathrm{dL}$ and 36 $\mathrm{ngr} / \mathrm{mL}$ ) confirming iron deficiency anemia. Serial stool examinations for ova and parasites were negative. His abdominal ultrasonography revealed hepatomegaly with hypoechoic areas. Serological testings for salmonella, brucella, and viral hepatitis were negative. Bone marrow aspiration revealed an abundance of mature eosinophils with no evidence of blast cells (Figure 1a, b). Total IgE count was $1307 \mathrm{kU} / \mathrm{L}$ (normal range: 0-100 kU/L) and lgG count was $1500 \mathrm{mg} / \mathrm{dL}$. Serology for Toxocara revealed an elevated Ig $\mathrm{G}$ titer (++++) by ELISA assay and Western blot (+). A diagnosis of VLM was established and albendazole $(15 \mathrm{mg} / \mathrm{kg} / \mathrm{d})$ was administered for 7 days. After this therapy leukocytosis and eosinophilia persisted and a second course of albendazole combined with prednisolone $(2 \mathrm{mg} / \mathrm{kg} / \mathrm{d}$ ) was administered for another 7 days. After 3 weeks of therapy with albendazole, the eosinophil count mildly decreased and hepatomegaly resolved. At the end of two months, the patient was well on physical examination but eosinophilia persisted.

\section{DISCUSSION}

Toxocariasis is a multisystemic disease of parasitic zoonosis that occurs especially in young children (2). There are 3 major clinical syndromes associated with human toxocariasis; covert toxocariasis, ocular larva migrans and VLM (1). VLM is the most prevalent type of the disease and the classical presentation includes fever, hepatomegaly and eosinophilia $\left(>500 / \mathrm{mm}^{3}\right)$. The disease is common in toddlers with a history of pica and exposure to puppies $(3,4)$. Our patient, a 2.5 year old boy, was at a high risk because of the history of pica, unsanitary playing habits and tendency to place fingers in his mouth.

Eosinophilia commonly occurs in parasitic infestations and allergies. Parasitic infections are the most common causes of eosinophilia (5). A presumptive diagnosis was established in our patient

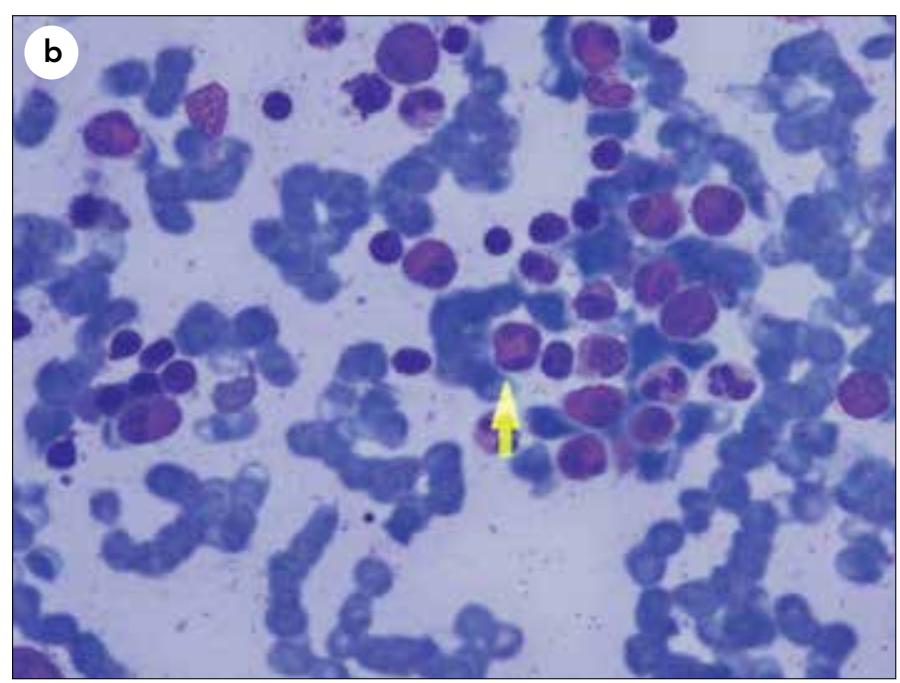

with leukocytosis, eosinophilia (>20\%), fever and hepatomegaly, but the examination of stool samples for evidence of larvae was negative. Hypergammaglobulinemia, as a supportive laboratory finding, existed and serologic testing for Toxocara with high titers confirmed the diagnosis. The prevalence of positive toxocara serology in the general populationestablishes that most children and adults are asymptomatic, and physiological reactions to Toxocara infection probably depend on the host's immune response and the parasitic load $(1,6)$. When symptoms do occur, they are the result of migration of second stage Toxocara larvae through the body. In VLM, larvae migration incites inflammation of internal organs, and symptoms depend on the organ(s) affected (1). Hepatic involvement in VLM is common due to portal venous drainage of visceral organs. Gonzalez et al. (7) reported hypoechoic areas in the liver in 50\% of their cases with Toxocariasis. Our patient had hepatomegaly, proved by ultrasound and accompanied by hypoechoic areas in the liver belonging associated with hepaticnvolvement.Some antihelminthic drugs are used but there is no consensus on the duration of the therapy. Adjunctive corticosteroids are recommended to limit inflammatory responses resulting from release of Toxocara antigens by dying parasites (8). Our patient showed symptomatic improvement after 14 days of Albendazole therapy, combined with corticosteroids in the second week, to suppress inflammation. He was in recovery at the end of two months but seropositivity for T. canispersisted. Glickman et al. (9) reported thaperiodic reinfection may cause repeated antigen stimulation and so antibodies may persist for long periods.

Several cases present with endocarditis, Henoch-Schonlein purpura or nephrotic syndrome (10-12). Although death is rare, long term morbidity is present with toxocariasis. Transmission can be minimized by public health measures.

\section{CONCLUSION}

Visceral larva migrans (VLM) is usually suspected in a young child with geophagia and exposure to pets, with fever and hepatomegaly, with leukocytosis and marked eosinophilia.Infection with Toxocara species is probably far more common than is reported, 
given the large stray dog population and areas of primitive sanitary conditions. Clinicians can avoid erroneous diagnosis and therapeutic interventions by considering this parasitic infection.

\section{Conflict of Interest}

No conflict of interest was declared by the authors.

\section{REFERENCES}

1. Kayes SG. Human toxocariasis andthe visceral larva migrans syndrome. Correlative immunopathology. Chem Immunol 1997; 66: 92-124.

2. Arango CA. Visceral larva migrans and the hypereosinophilia syndrome. South Med J 1998; 91: 882-3. [CrossRef]

3. Figueiredo SD, Taddei JA, Menezes JJ, Novo NF, Silva EO, Cristovao HL, et al. Clinical epidemiological study of toxocariasis in a pediatric population. J Pediatr 2005; 81: 126-32. [CrossRef]

4. Fan CK, Hung CC, Du WY, LiaoCW, Su KE. Seroepidemiology of Toxocara canis infection among mountain aboriginal school children living in contaminated districts in eastern Taiwan. Trop Med Int Health 2004; 9: 1312-8. [CrossRef]

5. Hayashi E, Tuda J, Imada M, Akao N, Fujita K. The high prevalence of asymptomatic Toxocara infection among schoolchildren in
Manado, Indonesia. Southeast Asian J Trop Med Public Health 2005; 36: 1399-406.

6. Despommier D. Toxocariasis: clinical aspects, epidemiology, medical ecology, and molecular M aspects. Clin Microbiol Rev 2003; 16: 265-72. [CrossRef]

7. Gónzalez MT, Ibañez O, Balcarce N, Nanfito G, Kozubsky L, Radman $\mathrm{N}$, et al. Toxocariasis with liver involvement. Acta Gastroenterol Latinoam 2000; 30: 187-90.

8. Barisani-Asenbauer T, Maca SM, Hauff W, Kaminski SL, Domanovits $\mathrm{H}$, Theyer I, et al. Treatment of ocular toxocariasis with albendazole. J Ocul Pharmacol Ther 2001; 17: 287-94. [CrossRef]

9. Glickman L, Schantz P. Epidemiology and pathogenesis of zoonotic toxocariasis. Epidemiol Rev 1981; 3: 230-50.

10. Abe K, Shimokawa H, Kubota T, Nawa Y, Takeshita A. Myocarditits associated with visceral larva migrans due to Toxocara canis. Intern Med 2002; 41: 706-8. [CrossRef]

11. Hamidou MA, Gueglio B, Cassagneau E, Trewick D, Grolleau JY. Henoch-Schonlein purpura associated with Toxocara canis infection. J Rheumatol 1999; 26: 443-5.

12. Shetty AK, Aviles DH. Nephrotic syndrome associated with Toxocara canis infection. Ann Trop Paediatr 1999; 19: 297-300.[CrossRef] 